\title{
Asplenium nidus L. pada Beberapa Pohon Inang di Kawasan Taman Wisata Alam Bukit Kelam, Kabupaten Sintang, Kalimantan Barat
}

\author{
Asplenium nidus L. on Some Host Trees in Bukit Kelam Natural Recreation Park, \\ Sintang, West Kalimantan
}

\section{Deden Mudiana}

Kebun Raya Purwodadi, Jalan Raya Purwodadi, Pasuruan, Jawa Timur 67163

E-mail:dmudiana@yahoo.com

\begin{abstract}
Asplenium nidus L. is one of epiphyte fern that commonly known by most people. This research aims to observe distribution pattern of Asplenium nidus that growth on host trees at Taman Wisata Alam Bukit Kelam. One hundred sixty Asplenium nidus have been observed grow on 66 individual host trees. Most of them grow on zone 4 (midle part of branches of three) on the host trees. Surface of bark on host trees and form of branches are environment factors that influence the growth of Asplenium nidus.
\end{abstract}

Key words: Asplenium nidus L., host trees, Bukit Kelam Natural Recreation Park

Diterima: 05 Oktober 2007, disetujui: 14 Januari 2008

\section{Pendahuluan}

Asplenium nidus L. adalah salah satu jenis tumbuhan paku yang secara alami hidup sebagai epifit. Masyarakat Indonesia mengenalnya dengan berbagai macam nama daerah, seperti: kadaka, badaba (Sunda), simbar merah (Jawa), lokot (Kalimantan), tatoe hoekoen, tato hukung (Maluku), bunga minta doa (Bugis), paku sarang burung, pakis sarang burung (Indonesia) (Sastrapradja et al., 1979a).

Daerah penyebaran jenis paku ini adalah Kawasan Malesiana, termasuk Indonesia. Asplenium nidus L. umumnya dapat tumbuh dari daerah pantai sampai dengan daerah pegunungan pada ketinggian hingga 2.500 meter di atas permukaan laut (dpl). Walaupun tumbuh sebagai epifit, Asplenium nidus L. kadang-kadang dapat dijumpai tumbuh di atas permukaan tanah. Dalam hidupnya, jenis ini juga menyukai tempat yang agak lembab, ternaungi atau agak ternaungi dan tidak menyukai sinar matahari langsung (Mansur, 2001; Ferial et al., 1999; Murakami et al., 1999). Di Hutan Taman Wisata Alam Ruteng, yaitu pada daerah lereng Gunung Mandasawa, jenis ini dijumpai tumbuh di lantai hutan yang lembab dan ternaungi (Wiriadinata, 1998).

Asplenium nidus dapat pula tumbuh sebagai epifit pada liana. Hal ini seperti dikemukakan oleh Mansur et al., (2004) dari hasil penelitian mengenai tempat hidup Asplenium nidus di Taman Nasional Gunung Halimun. Secara vertikal jenis paku ini dijumpai tumbuh pada ketinggian antara 0,4-20 meter dari permukaan tanah pada inangnya, dan paling banyak dijumpai pada ketinggian 0,1-4,9 meter. Umumnya jenis ini dijumpai pada daerah lembah dengan kondisi kelembaban yang tinggi. Murakami et al., (1999) menemukan tiga tipe kelompok genetik Asplenium nidus di TN Gunung Halimun, yang berbeda letak tempat tumbuhnya, baik pada pohon inang ataupun ketinggian tempat. Bahkan penelitian lanjutan yang dilakukan oleh Yatabe et al., (2001) menunjukkan bahwa terdapat 3 kelompok spesies kriptik Asplenium nidus yang terisolasi secara reproduktif. Spesies kriptik adalah spesies-spesies yang secara morfologis sangat mirip atau sama 
kenampakan morfologisnya tetapi secara genetik berbeda (Widyatmoko dan Irawati, 2007).

Informasi mengenai tempat tumbuh Asplenium nidus sebagai epifit pada pohon inangnya dapat menggambarkan karakter persebaran secara vertikal tempat tumbuhnya. Informasi ini akan lebih menjelaskan pada bagian mana dari pohon inang yang dapat ditumbuhi oleh Asplenium nidus. Pembagian zonasi pada pohon inang akan mempermudah mengetahui karakter tempat tumbuhnya sebagai epifit.

Penelitian ini bertujuan mengetahui persebaran tempat tumbuh Asplenium nidus sebagai epifit pada beberapa pohon inang dalam Kawasan Taman Wisata Alam Bukit Kelam.

\section{Metode Penelitian}

Penelitian dilaksanakan di Kawasan TWA Bukit Kelam pada tanggal $8-19$ Juli 2006. Posisi geografisnya berada pada $0^{0} 05^{\prime} 25^{\prime \prime}$ $-0^{0} 05^{\prime} 27^{\prime}$ " Lintang Utara (LU) dan $111^{0} 34^{\prime} 11^{\prime}$ " - 111034'13" Bujur Timur (BT). Lokasi penelitian terletak di dalam kawasan hutan di kaki Bukit Kelam, yang secara administratif masih termasuk ke dalam wilayah Desa Tekang, Kecamatan Kelam Permai, Kabupaten Sintang, Kalimantan Barat. Posisi geografisnya terletakpada $0^{0} 4^{\prime} \mathrm{LU}$ dan $111^{0} 38^{\prime} \mathrm{BT}$.

Kawasan ini memiliki topografi datar sampai berbukit dengan ketinggian hingga 800 mdpl (pada bagian puncak). Tipe tanahnya didominasi oleh tipe podsolik merah kuning. Status penunjukan kawasan ini berdasarkan pada SK Menhut No 594/Kpts-II/1992 pada tanggal 6 Juni 1992 dengan luas 520 hektar (Anonim, 2005).

Tipe iklim kawasan ini menurut Schmidt dan Ferguson termasuk klasifikasi tipe A dengan curah hujan rata-rata per tahun 263 $\mathrm{mm}$. Suhu udara minimum sebesar $22^{\circ} \mathrm{C}$ dan maksimum $32^{\circ} \mathrm{C}$ dengan kelembaban antara 60 70\% (Anonim, 2008).

Peralatan yang digunakan dalam penelitian ini adalah teropong, GPS tipe Garmin etrex vista, kamera digital, hagameter, kompas, dan alat tulis. Bahan penelitian yang sekaligus menjadi objek penelitian ini adalah Asplenium nidus yang tumbuh menempel pada pohon inang.

Pengamatan dilakukan dengan metode eksploratif, yaitu mengikuti atau membuat jalur rintisan di dalam kawasan. Jalur rintisan dibuat mulai dari hutan di batas Desa Tekang hingga areal di sekitar kaki Bukit Kelam. Panjang jalur yang dilalui adalah sepanjang sekitar 3,6 km. Jarak ini diperoleh dengan menghitung jarak datar antara dua titik posisi geografis dengan menggunakan GPS, yaitu titik awal jalur rintisan $\left(0^{0} 4^{\prime} 51,2\right.$ '"LU dan $111^{0} 38^{\prime} 132,2$ '” BT $)$ dan titik akhir lokasi di sekitar kaki Bukit Kelam $\left(0^{0} 4^{\prime} 47,9^{\prime \prime} \mathrm{LU}\right.$ dan $111^{0} 38^{\prime} 14,3^{\prime \prime}$ BT). Perhitungan dan dokumentasi posisi geografis yang tersimpan di GPS selanjutnya ditransfer dengan menggunakan program MapSource.

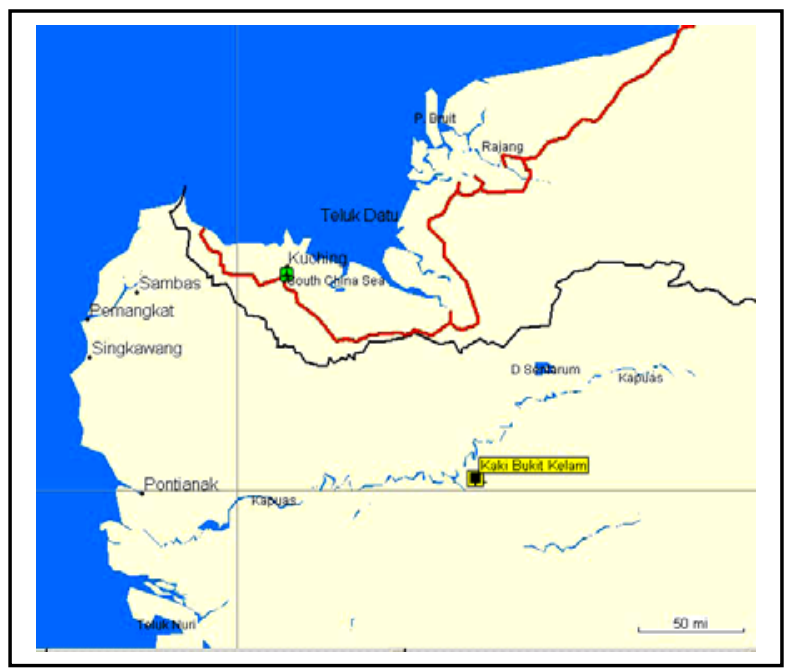

Gambar 1. Lokasi penelitian, TWA Bukit Kelam 
Pengamatan dan pengumpulan data dilaksanakan dengan menentukan setiap pohon yang ditumbuhi oleh Asplenium nidus sepanjang jalur rintisan yang dilalui. Setiap pohon yang ditempeli Asplenium nidus didata sebagai pohon inang. Batasan pohon yang digunakan adalah memiliki batang utama yang jelas, dengan ukuran diameter batang setinggi dada lebih dari atau sama dengan $20 \mathrm{~cm}$ (Kusmana dan Istomo, 1995).

Data yang dicatat dan dikumpulkan meliputi: jumlah dan jenis pohon inang, jumlah Asplenium nidus yang dijumpai pada tiap pohon inang, zonasi tempat menempelnya Asplenium nidus pada pohon inang, serta ketinggian letak Asplenium nidus pada pohon inang.

Perincian zonasi pohon inang sebagai tempat tumbuhnya Asplenium nidus pada penelitian ini mengikuti metode Johansson (1975), untuk anggrek epifit. Pohon inang dibagi menjadi 5 zona, Zona 1: pangkal pohon (1/3 batang utama bagian bawah), Zona 2: batang utama hingga percabangan pertama ( $2 / 3$ bagian batang utama bagian atas), Zona 3: basal percabangan (1/3 panjang pangkal cabang), Zona 4: tengah percabangan (1/3 bagian tengah cabang), dan Zona 5: percabangan terluar ( $1 / 3$ cabang atas atau terluar). Secara sederhana penggambaran pembagian zonasi tersebut seperti terlihat pada Gambar 2.
Data yang diperoleh akan dideskripsikan untuk mengetahui kecenderungan tempat tumbuh Asplenium nidus pada pohon inangnya.

\section{Hasil dan Pembahasan}

\section{Deskripsi Asplenium nidus L.}

Perawakannya berupa perdu epifit, batang pendek. Susunan daun melingkar pada batang sehingga tersusun menyerupai bentuk seperti sarang burung. Daun tunggal; berwarna hijau muda-tua mengkilap; berbentuk oblong hingga obovate, panjang dapat mencapai 150 meter dan lebar $30 \mathrm{~cm}$; tepi daun rata; ujung lancip; daun muda muncul pada bagian tengah batang. Kotak spora tersusun dalam bentuk garis-garis menyirip rapat pada permukaan bawah daun, berwarna coklat. Tumbuh sebagai epifit atau dapat pula dijumpai di permukaan tanah dan batu pada tempat-tempat yang sejuk, lembabdanternaungi(Sastrapradja et al., 1979a).

Di Kawasan Malesiana terdapat sebanyak 650 jenis Asplenium. Holttum (1968) mengelompokkannya ke dalam 5 group, yaitu: 1) Group A. robustum, 2) Group A. caudatum 3) Group A. tenerum, 4) Group A. unilaterale, dan 5) Group A. scolopendrioides. Asplenium nidus termasuk ke dalam group Asplenium tenerum bersama dengan: A. belengeri, $A$. scortechinii, A. salignum, A. squamulatum, A. tenerum, dan A. phyllitidis. Sinonim untuk Asplenium nidus L. adalah Thamnopteris nidus Presl.

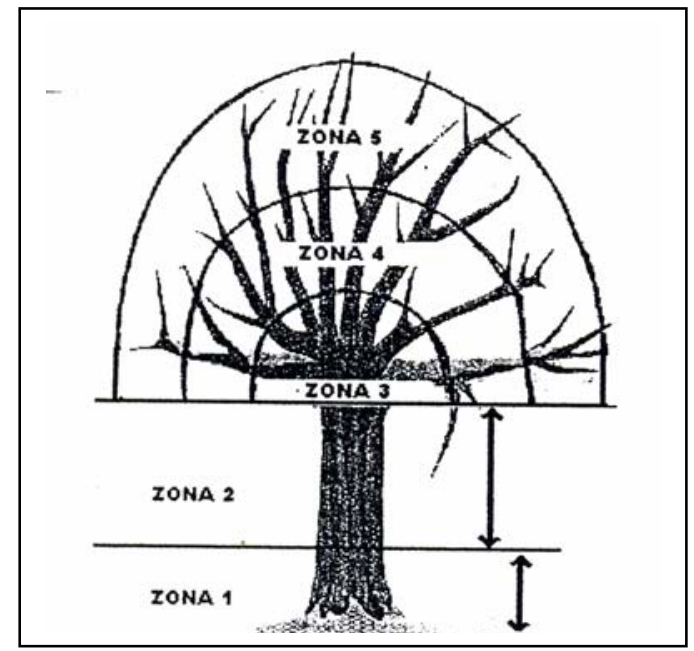

Gambar 2. Sketsa pembagian zonasi Asplenium nidus pada pohon inang 


\section{Asplenium nidus dan pohon inangnya}

Dari pengamatan yang dilakukan sepanjang 3,6 km pada jalur rintisan yang dilalui berhasil diperoleh data sebanyak 160 individu Asplenium nidus yang hidup sebagai epifit pada 66 individu pohon inang. Tercatat sebanyak 14 jenis pohon yang menjadi inang bagi Asplenium nidus (Gambar 3). Adapun pada pembagian zonasinya, keberadaan Asplenium nidus pada pohon inang dapat dilihat pada Gambar 4, dan ketinggian rata-rata letak Asplenium nidus pada tiap zona pohon inangnya terlihat pada Gambar 5.

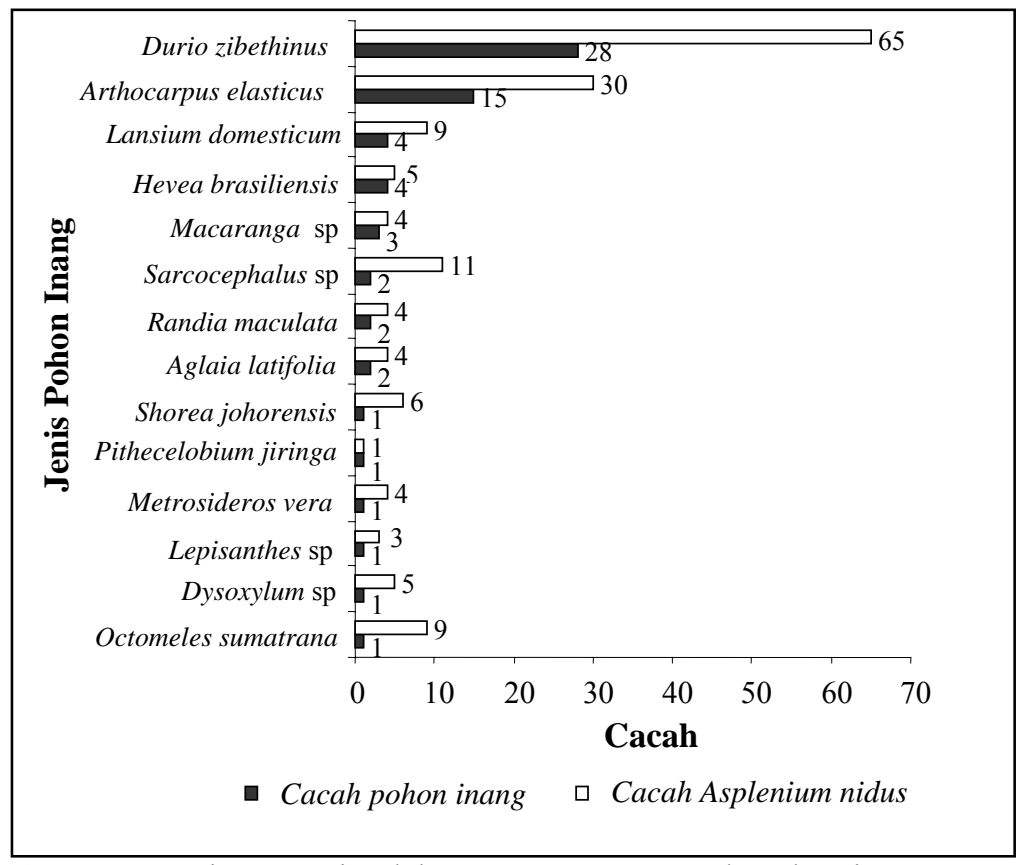

Gambar 3. Histogram jumlah Asplenium nidus pada pohon inang

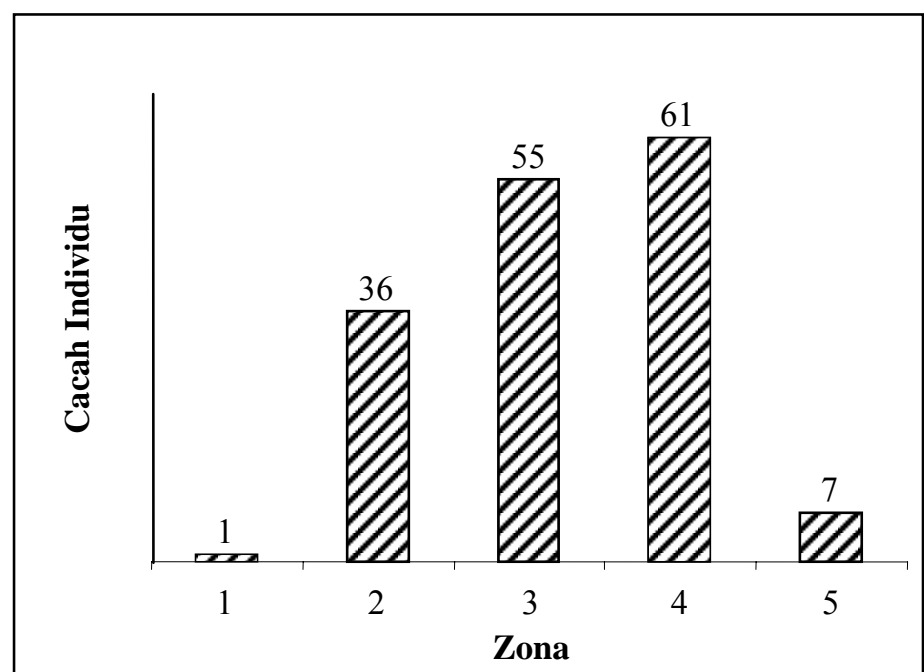

Gambar 4. Cacah Asplenium nidus berdasarkan zona pada pohon inangnya 
Pengamatan yang dilakukan selama penelitian menghasilkan beberapa data yang dapat menggambarkan tempat tumbuh Asplenium nidus sebagai epifit. Dari 160 individu Asplenium nidus yang teramati, sebanyak 65 individu (40,625\%) dijumpai hidup sebagai epifit pada pohon durian (Durio zibethinus). Pohon durian adalah pohon inang Asplenium nidus yang paling banyak tercatat dalam pengamatan di lapangan (sebanyak 28 pohon). Letak Asplenium nidus pada pohon durian sebagian besar berada pada zona 3 (sebanyak 27 individu), disusul kemudian berada pada zona 4, yaitu 26 individu.

Pohon Durio zibethinus yang dijumpai di lokasi penelitian memiliki perawakan berupa pohon besar dan tinggi dengan percabangan yang agak lebat. Tingginya dapat mencapai 30 meter.

Pohon inang berikutnya yang jumlahnya cukup banyak tercatat dalam pengamatan adalah jenis Artocarpus elasticus, sebanyak 15 pohon. Asplenium nidus yang menempel pada jenis ini tercatat sebanyak 35 individu (18,75\%). Sama halnya dengan Durio zibethinus, pohon inang ini ditumbuhi oleh Asplenium nidus paling banyak yaitu pada zona 3 (sebanyak 13 individu). Pada zona 4 dijumpai sebanyak 8 individu Asplenium nidus. Perawakan pohon ini berupa pohon besar dengan tinggi dapat mencapai 50 meter. Memiliki percabangan rapat, sehingga tajuknya terlihat rimbun.

Kondisi seperti ini dijumpai juga pada pohon-pohon inang lainnnya. Percabangan yang rapat menjadikan pohon-pohon tersebut memiliki kesempatan untuk ditumbuhi berbagai macam epifit, termasuk Asplenium nidus. Asplenium nidus yang menempel banyak dijumpai hidup pada zona 3 dan atau zona 4 . Zona 3 adalah daerah pangkal percabangan, yaitu hingga $1 / 3$ bagian pangkal percabangan. Letaknya tersebut sangat memungkinkan bagi tumbuhan epifit untuk hidup dengan baik, karena sangat memungkinkan di daerah tersebut terkumpul aliran air hujan dari cabangcabang pohon sebelum selanjutnya mengalir melalui batang utama (steam flow) menuju permukaan tanah. Biji-biji yang halus, spora, serasah guguran daun, akan terbawa air dan terkumpul di daerah ini, yang selanjutnya akan menjadi tempat tumbuh yang sesuai bagi epifit.
Zona 3 juga merupakan areal pada pohon inang yang terlindung dari sinar matahari secara langsung. Kerimbunan tajuk pohon melindungi areal ini dari panas matahari langsung, sehingga kondisi kelembaban udarnya terjaga.

Secara keseluruhan, Asplenium nidus paling banyak dijumpai tumbuh pada zona 4 . Zona 4 adalah daerah yang terletak di tengah percabangan, yaitu $1 / 3$ bagian percabangan tengah. Letak dan kondisinya terdiri dari banyak percabangan, sehingga terdapat banyak celah atau ruang yang dapat menampung air, serasah, spora, biji, ataupun substrat lainnya yang terbawa oleh air ataupun angin. Posisi percabangan yang rapat membentuk berbagai ukuran sudut yang memungkinkan terbentuknya ruang dan celah terkumpulnya substrat dan serasah serta air sebagai tempat tumbuh epifit.

Letaknya yang berada pada bagian tengah percabangan tajuk pohon, memungkinkan pula untuk terlindung dari sinar matahari langsung. Kondisi seperti ini hampir serupa dengan kondisi pada zona 3.

Mengingat untuk tumbuhnya Asplenium nidus memerlukan kondisi yang lembab, tersedia banyak substrat dan nutrisi makanan, terlindung dari sinar matahari langsung (Mansur et al., 2004; Ferial et al., 1999; Yatabe et al., 2001) maka zona 3 dan zona 4 pada pohon inang merupakan tempat tumbuh yang sangat ideal bagi jenis ini.

Asplenium nidus yang tercatat tumbuh pada zona 1 dan 2 , dimana posisinya berada pada batang utama, jumlahnya sedikit (zona 1 terdapat 1 individu, dan zona 2 sebanyak 36 individu). Keberadaan Asplenium nidus pada zona ini sangat dipengaruhi oleh karakter dari permukaan batang pohon inangnya. Kondisi permukaan batang/cabang pohon inang yang kasar, akan mengakibatkan tersedianya ruangruang tempat tertimbunnya serasah, substrat hasil serasah yang lapuk, air dan juga spora yang selanjutnya akan tumbuh menjadi individu baru. Permukaan batang atau cabang pohon inang yang halus akan mengakibatkan air, substrat, serasah, dan spora akan langsung terbawa aliran air hujan. Durio zibethinus dan Artocarpus elasticus merupakan jenis pohon yang memiliki permukaan batang yang kasar, 
beralur dan mengelupas (Sastrapradja et al., 1979b). Jenis ini juga memiliki tajuk yang rimbun dengan percabangan yang banyak. Octomeles sumatrana, Pithecellobium jiringa, dan Macaranga sp, memiliki permukaan batang yang halus, sehingga sedikit memiliki ruang yang dapat menahan serasah, substrat dan air yang dapat menjadi tempat tumbuh epifit. Kesemuanya akan terbawa dan tercuci oleh aliran air yang jatuh melalui batangnya.

Zona 5 terletak pada bagian terluar dari tajuk pohon. Jumlah Asplenium nidus yang tercatat hanya 7 individu. Hal ini berkaitan dengan lokasinya yang langsung mendapatkan sinar matahari secara penuh. Kondisi semacam ini tidak sesuai bagi Asplenium nidus, yang lebih menyukai tumbuh pada tempat yang agak lembab dan ternaungi dari sinar matahari secara langsung (Sastrapradja et al., 1979a).

Berdasarkan pada tinggi rata-rata letak Asplenium nidus pada pohon inangnya (Gambar 5), terlihat bahwa ketinggiannya mengikuti zonasinya. Artinya makin tinggi letak Asplenium nidus pada pohon inang maka posisinya terletak pula pada zona yang lebih tinggi. Kisaran tinggi letak Asplenium nidus pada tiap-tiap zona adalah sebagai berikut: Zona 1 = pada ketinggian hingga 1 meter, Zona $2=2-20$ meter, Zona $3=4-26$ meter, Zona 4 $=4-26$ meter, dan Zona $5=18-28$ meter. Hal ini mengindikasikan bahwa habitus dari pohonpohon inang tersebut berupa pohon besar yang tinggi. Namun ternyata tinggi pohon inang tersebut tidak selalu berkaitan dengan banyaknya Asplenium nidus yang tumbuh menempel sebagai epifit. Hasil penelitian yang dilakukan oleh Mansur et al., (2004) di Taman Nasional Gunung Halimun menunjukkan bahwa Asplenium nidus paling banyak tumbuh pada ketinggian 0,1-4,9 di atas permukaan tanah. Keadaan semacam ini dikarenakan pohon inang yang ada kebanyakan berupa anakan dan permudaan pohon. Daerah tersebut memiliki kelembaban udara yang tinggi dengan temperatur yang rendah, sehingga menjadi lingkungan yang cocok bagi perkecambahan spora Asplenium nidus. Faktor lingkungan tempat tumbuh yang sesuai bagi Asplenium nidus merupakan hal yang berkaitan dengan jumlah dan keberadaan jenis ini.

Faktor ini juga yang dapat menjadi penyebab mengapa pada lokasi penelitian di TWA Bukit Kelam, Asplenium nidus lebih banyak dijumpai pada zona 4, yaitu pada bagian $2 / 3$ tajuk. Kerimbunan tajuk pohon inang dapat memelihara kelembaban udara, kondisi naungan dan suhu lingkungan. Hal ini akan mendukung kehidupan Asplenium nidus, terutama untuk perkecambahan sporanya.

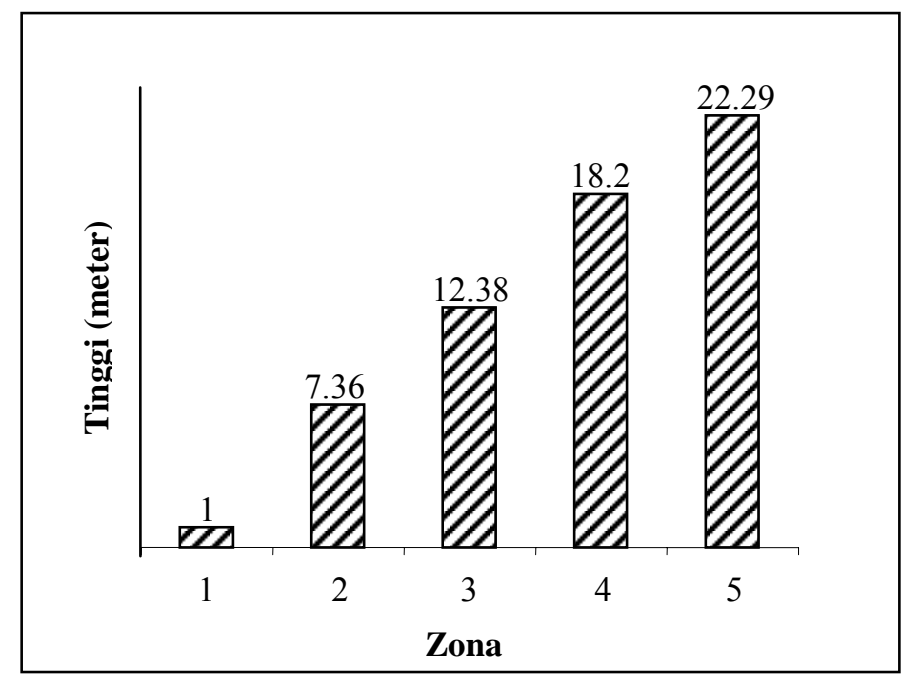

Gambar 5. Cacah tinggi rata-rata letak Asplenium nidus pada pohon inangnya 
Data pengamatan menunjukan kisaran tinggi letak Asplenium nidus pada zona 3 dan zona 4 adalah sama ( 4 - 26 meter). Hal ini dapat diartikan bahwa zona 4 yang merupakan $1 / 3$ bagian tengah tajuk, terletak relatif sejajar dengan zona 3 , sehingga dapat diilustrasikan bahwa umumnya pohon inang yang diamati memiliki tajuk yang lebar. Dengan demikian kelembaban udara dan kondisi naungan di lingkungan tersebut tetap terjaga. Karakter seperti ini semakin mendukung bahwa pohonpohon inang yang diamati adalah tempat yang disukai oleh Aspenium nidus untuk tempat tumbuhnya. Sebagai pembanding dapat dilihat pada Asplenium nidus yang tumbuhan di sebagai epifit di TN Gunung Halimun. Di lokasi tersebut, umumnya Asplenium nidus dijumpai menempel pada batang dengan kondisi ternanungi dan lembab. Meskipun secara vertikal banyak dijumpai pada ketinggian 0,1-4,9 meter. Hal ini dikarenakan pohon inangnya berupa pohon dalam tingkatan tiang (Mansur et al., 2004).

\section{Kesimpulan}

Terdapat sebanyak 160 individu Asplenium nidus tumbuh pada 14 jenis, pohon inang yang terdiri atas 66 individu pohon inang di Kawasan TWA Bukit Kelam. Jumlah Asplenium nidus terbanyak tumbuh pada pohon inang Durio zibethinus dan Artocarpus elasticus. Berdasarkan zonasinya, Asplenium nidus paling banyak tumbuh di zona 4 .

\section{Daftar Pustaka}

Anonim. 2005. Informasi kawasan konservasi Kalimantan Barat dan upaya konservasi lainnya. Balai Konservasi Sumber Daya Alam Kalimantan Barat.

Anonim. 2008. Taman Wisata Alam Bukit Kelam. http:// www.bpkh3.go.id/proplain/tamanwisataalam/ bukit kelam.htm. 11/02/2008.

Ferial, E.W., Dasuki, U.A. dan Widodo, S.H. 1999. Studi keanekaragaman tumbuhan paku di Ranca Upas, Kawah Putih (Gunung Patuha) dan sekitarnya, Bandung Selatan. Dedy Darnaedi et al., (Penyunting). Pros. Sem. Nas. Konservasi Flora Nusantara. UPT Balai Pengembangan Kebun Raya - LIPI. Bogor.
Holltum, R.E. 1968. Flora of Malaya: Ferns of Malaya. Government Printing Office, Singapore.

Johansson, D.R. 1975. Ecology of epiphytic orchids in West African rain forest. American Orchid Society Bull. 44: 125-136.

Kusmana, C. dan Istomo. 1995. Ekologi Hutan (Bahan kuliah, tidak dipublikasikan). Lab. Ekologi Hutan, Fakultas Kehutanan, Institut Pertanian Bogor. Bogor.

Mansur, M. 2001. Inventarisasi flora kawasan hutan Dipterocarpaceae di Taman Nasional Betung Karihun, Sungai Mendalam, Kalimantan Barat. Laporan Teknik Proyek Inventarisasi dan Karakterisasi Sumberdaya Hayati. Sunaryo et al., (Penyunting). Pusat Penelitian dan Pengembangan Biologi-LIPI. Bogor.

Mansur, M., Kohyama, T. dan Simbolon, H. 2004. Distribusi vertikal dan horizontal Asplenium nidus L. di Taman Nasional Gunung Halimun, Jawa Barat. Berita Biologi 7 (1\&2).

Mudiana, Tulabi, D., Baris, P., Pai'I dan Rais. 2006. Laporan Perjalanan Eksplorasi Flora di Kawasan TWA Baning dan TWA Bukit Kelam, Kabupaten Sintang, Kalimantan Barat. (tidak dipublikasikan). UPT Balai Konservasi Tumbuhan - Kebun Raya Purwodadi, LIPI.

Murakami, N., Yatabe, Iwasaki, H., Darnaedi, D. and Iwatsuki, K. 1999. Molecular $\alpha$ taxonomy of a morphologically simple fern Asplenium nidus complex from Mt. Halimun National Park, Indonesia. In: Kato, M. (Eds.). The Biology of Biodiversity, pp. 53-66. Springer - Verlog, Tokyo, Japan.

Sastrapradja, S., Afriastini, J.J., Darnaedi, D. dan Widjaya, E.A. 1979a. Jenis Paku Indonesia. Lembaga Biologi Nasional - LIPI. Bogor.

Sastrapradja, S., Kartawinata, K., Soetisna, U., Roemantyo, Wiriadinata, H. dan Soekardjo, S. 1979b. Kayu Indonesia. Lembaga Biologi Nasional - LIPI. Bogor.

Widyatmiko, D. dan Irawati. 2007. Kamus istilah konservasi. Pusat konservasi Tumbuhan Kebun raya Bogor-LIPI. Bogor.

Wiriadinata, H. 1998. Floristic distribution of Ruteng Nature Recreation Park. In: Herwin, S. (Eds.). Biodiversity Research Series 2, The Natural Resources of Flores Island. Research and Development Center of Biology, The Indonesian Institute of Sciences. Bogor.

Yatabe, Y., Masuyama, S., Darnaedi, D. and Murakami, N. 2001. Molecular systematic of the Asplenium nidus complex from Mt. Halimun National Park, Indonesia: evidence for reproductiv isolation among three sympatric RBCL secuence type. American J. of Botany 88 (8): 1517-1522. 